\title{
The genus Metacyclops Kiefer in Australia (Crustacea: Copepoda: Cyclopoida), with description of two new species
}

\author{
T. Karanovic \\ Western Australian Museum, Francis Street, Perth, Western Australia 6000, Australia
}

\begin{abstract}
Two new species of the genus Metacyclops Kiefer, 1927 are described from subterranean waters of Western Australia, one from the Kimberley region and the other from the Pilbara region. They both belong to the "trispinosus"-group, which has a clear Eastern Gondwana connection and the centre of diversity in Australia. A phyletic tree of this group in Australia is proposed. Metacyclops kimberleyi sp. nov. is distinguished from other members of the group by at least two autapomorphies: the exceptionally long dorsal seta on the caudal rami and the maxilliped with only seven armature elements. The only clear autapomorphy of $M$. pilbaricus sp. nov. seems to be its unusual body shape. An antenna without exopod and the second endopodal segment of this appendage with only six setae is a synapomorphy that suggests a close relationship between these two new species. As the genus Metacyclops in Australia already has seven valid species, a key to aid in their identification, as well as a map of their distributions, are presented.
\end{abstract}

\section{INTRODUCTION}

At the beginning of the last century the famous Norwegian carcinologist G. O. Sars described Cyclops arnaudi based upon material collected by $O$. A. Sayce in 1901 from a swamp at St. Arnaud in Victoria (Sars, 1908). This species later became the first Australian representative of the genus Metacyclops, which was initially established as a subgenus of the genus Mesocyclops Sars, 1914 by Kiefer (1927). More than half a century after Metacyclops arnaudi was first described, intense investigation of the limnological characteristics of many Australian inland surface waters yielded numerous invertebrate specimens (Bayly, 1964; Bayly and Williams, 1964; 1966a; 1966b). Cyclopoid copepods from those studies were sent for identification to F. Kiefer in Germany, who reported $M$. arnaudi for the second time from two lakes in Victoria (Kiefer, 1967) and also described a new subspecies of this species from a lake in South Australia. However, recent reexamination of that material by Fiers (2001) showed that Kiefer (1967) was not dealing with $M$. arnaudi at all and, furthermore, transferred both taxa into the newly described genus Meridiecyclops. Unfortunately, the type material of $M$. arnaudi is no longer available (Hamond, 1987), so the original description of Sars (1908), with its fine illustrations, is all that was left of the first Australian Metacyclops. An unnamed and as yet undescribed species of Metacyclops was reported by Timms and Morton (1988), but this genus does not appear to have a significant diversity in Australian surface waters, and certainly nothing that could be compared with other continents of the Southern Hemisphere (see Dussart and Defaye, 1985).

Australian subterranean waters, on the other hand, were not investigated systematically until the last decade (Humphreys, 2001). Unexpectedly, the groundwater calcrete aquifers in the Australian arid zone come to the attention of stygobiologists and systematists on account of the diverse obligate stygofauna that is being found there by W. F. Humphreys and his colleagues from the Western Australian Museum (Humphreys, 1993). An unfolding plethora of stygal biodiversity has been found, including a number of higher order taxa variously new to science (e.g. Wilson and Ponder, 1992; Poore and Humphreys, 1992; 1998; Yager and Humphreys, 1996; Danielopol et al., 2000; Jaume and Humphreys, 2001; Jaume et al., 2001). The freshwater cyclopoids collected during that period were sent for identification to G. L. Pesce and his colleagues in Italy, who described Metacyclops mortoni from Cape Range peninsula and the Ashburton River, as the first subterranean representative of this genus in Australia (Pesce et al., 1996). This species was later found at two additional localities in the Pilbara Region (Port Hedland and Cossack near Karratha) by De Laurentiis et al. (1999). Two years later, the same authors (De Laurentiis et al., 2001) assigned two other cyclopoid species from Western Australia to the genus Metacyclops. The first one, $M$. fiersi, was described as a new species from three bores near Eneabba, while the second one was reported as $M$. 
cf. monacanthus Kiefer, 1928 from a number of bores at Paroo Station in the Murchison Region. In my recent study of the subterranean copepods from the Murchison Region (Karanovic, 2004) M. fiersi was found at 24 additional localities, but it was also transferred into the newly described genus Fierscyclops. De Laurentiis et al. (2001) noticed some differences between their material and the original description of M. monacanthus (Kiefer, 1928), which was known only from New Zealand (Kiefer, 1928), but they made a compromise and assigned it provisionally as con forme. I studied that species from 44 different localities from the Murchison Region and have found a number of differences between it and the New Zealand representative (although the type material was not examined), so it was described as a new species (M. laurentiisae) in Karanovic (2004). In the same monograph two other new species of the genus Metacyclops were described (M. superincidentis and $M$. pilanus) and one new group of species, with the clear Eastern Gondwana connection, was established. In this paper two new species from the same group are described, one from the Kimberley, the other one from the Pilbara regions of Western Australia.

Together with the two new species, the genus Metacyclops has now seven representatives in Australia. At the end of this paper a key to aid in their identification and a map of their distributions are presented.

\section{MATERIAL AND METHODS}

Samples were collected with haul-nets (mesh size 250 or 350 micrometers) from groundwater monitoring bores that are made by mining. companies for the purpose of water monitoring. Sometimes they are originally made for water abstraction or mineral exploration and later converted into monitoring bores. They are usually 10 to $20 \mathrm{~cm}$ in diameter, and may be lined entirely, or in part, by PVC tubing (the casing). This tubing may be open only at the bottom, or it may be pierced at one or more levels by holes of various sizes, referred to as "slots". The top may be securely capped or entirely open to the elements. Haul-nets are actually simple plankton nets of a different size suitable for the bore, which can range from 30 to $180 \mathrm{~mm}$ in diameter. Weighed nets were lowered down into the bore with one bottle screwed on its distal part than hauled through the water column, usually a number of times. All samples were sorted while alive under a dissecting microscope and the copepods were then fixed in $70 \%$ ethanol and assigned a field number (prefix BES). Many bores established for hydrogeological work, mineral exploration and water monitoring have prefixes or suffixes of relevance only to that drilling program. These codes are cited in the examined material for both species to aid specification of the location.

Specimens were dissected in Faure's medium, which was prepared following the procedure discussed by Stock and Vaupel Klein (1996). Dissected appendages were covered with a coverslip. For the urosome or the whole animal two human hairs were mounted between the slide and coverslip, so the parts could not be squashed. By moving the coverslip carefully by hand, the whole animal or a particular appendage could be positioned in different aspects, making possible the observation of morphological details. During the examination water slowly evaporated, and appendages or whole animals eventually remained in completely dry Faure's medium. All drawings were prepared using a drawing attachment (tube) on a Leica-DMLS brightfield compound microscope, with C-PLAN achromatic objectives. Specimens that were not drawn were examined in a mixture of equal parts of distilled water and glycerol and, after examination, were again preserved in $70 \%$ ethanol. Samples for the scanning electron microscopy were couted in gold and observed under the LEO FEG VPSEM microscope on the in-lens detectors, with working distances between 2 and $6 \mathrm{~mm}$ and accelerating voltages between 2 and $5 \mathrm{kV}$. All the material is deposited in the Western Australian Museum, Perth (prefix WAM).

Morphological terminology follows Huys and Boxshall (1991), except for the swimming legs armature formula, where a much more simplified version is used.

\section{SYSTEMATICS}

\section{Family Cyclopidae Burmeister, 1834}

Subfamily Cyclopinae Dana, 1853

Genus Metacyclops Kiefer, 1927

Metacyclops kimberleyi sp. nov. Figures 1, 2, 4-28, 46, 48 and 50

\section{Material Examined}

\section{Holotype}

Female (WAM C28628), Western Australia, Kimberley, Argyle Diamond Mine, groundwater monitoring bore 29D, $16^{\circ} 41^{\prime} 37^{\prime \prime} \mathrm{S}, 128^{\circ} 27^{\prime} 11^{\prime \prime} \mathrm{E}, 10$ October 2002, leg. W. F. Humphreys and R. Webb (BES 9693): dissected on two slides.

\section{Allotype}

Male (WAM C28629), Western Australia, Kimberley, Argyle Diamond Mine, groundwater monitoring bore 29D, 16 $41^{\prime} 37^{\prime \prime} \mathrm{S}, 128^{\circ} 27^{\prime} 11^{\prime \prime} \mathrm{E}, 10$ October 2002, leg. W. F. Humphreys and R. Webb (BES 9693): dissected on two slides. 


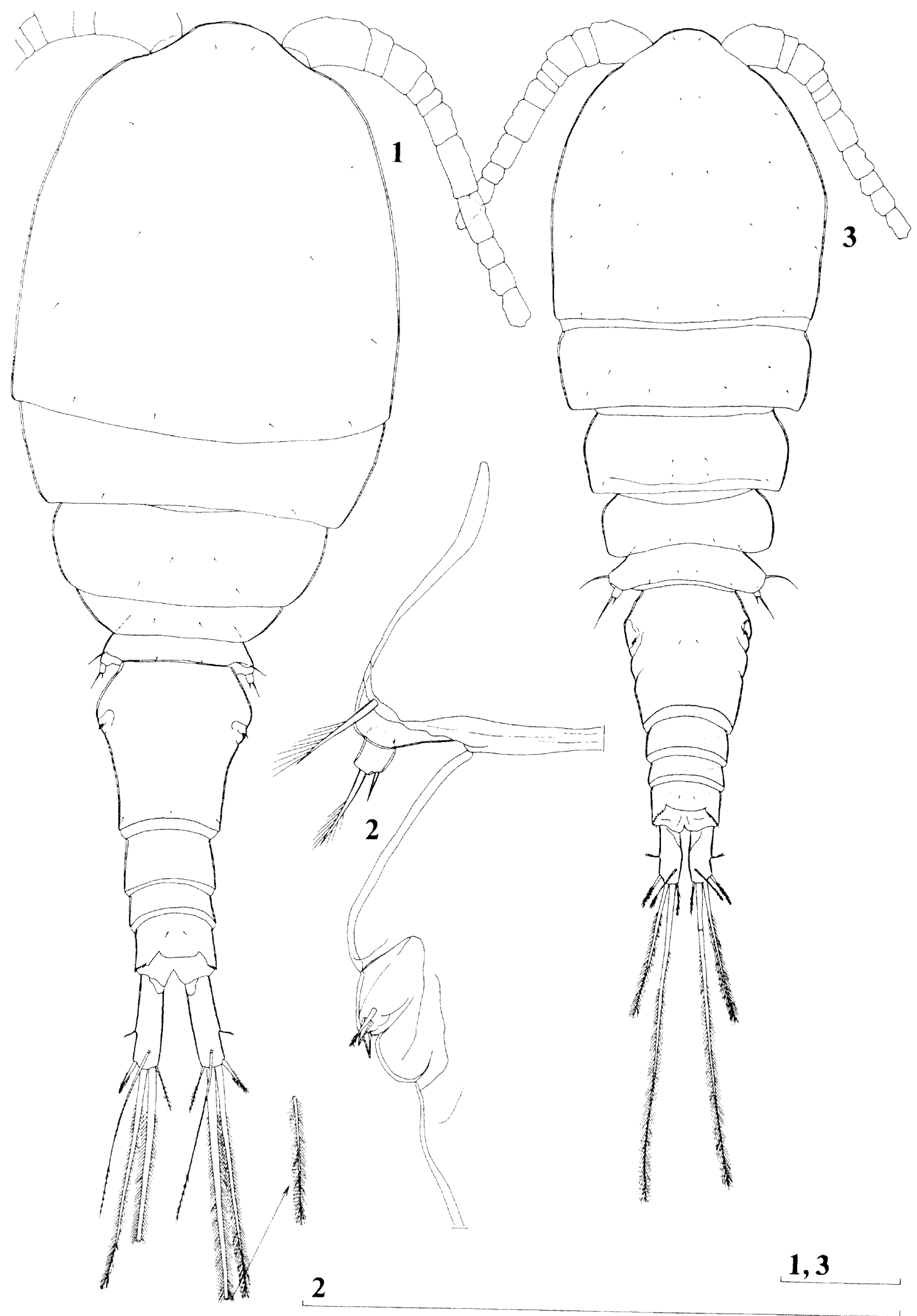

Figures 1-3 Metacyclops kimberleyi sp. now, holotype (female): 1 - habitus, dorsal view; 2 - left fifth and sixth legs, dorsal view; Metacyclops pilbaricus sp. nov., holotype (female): 3 - habitus, dorsal view. Scales $=0.1 \mathrm{~mm}$. 


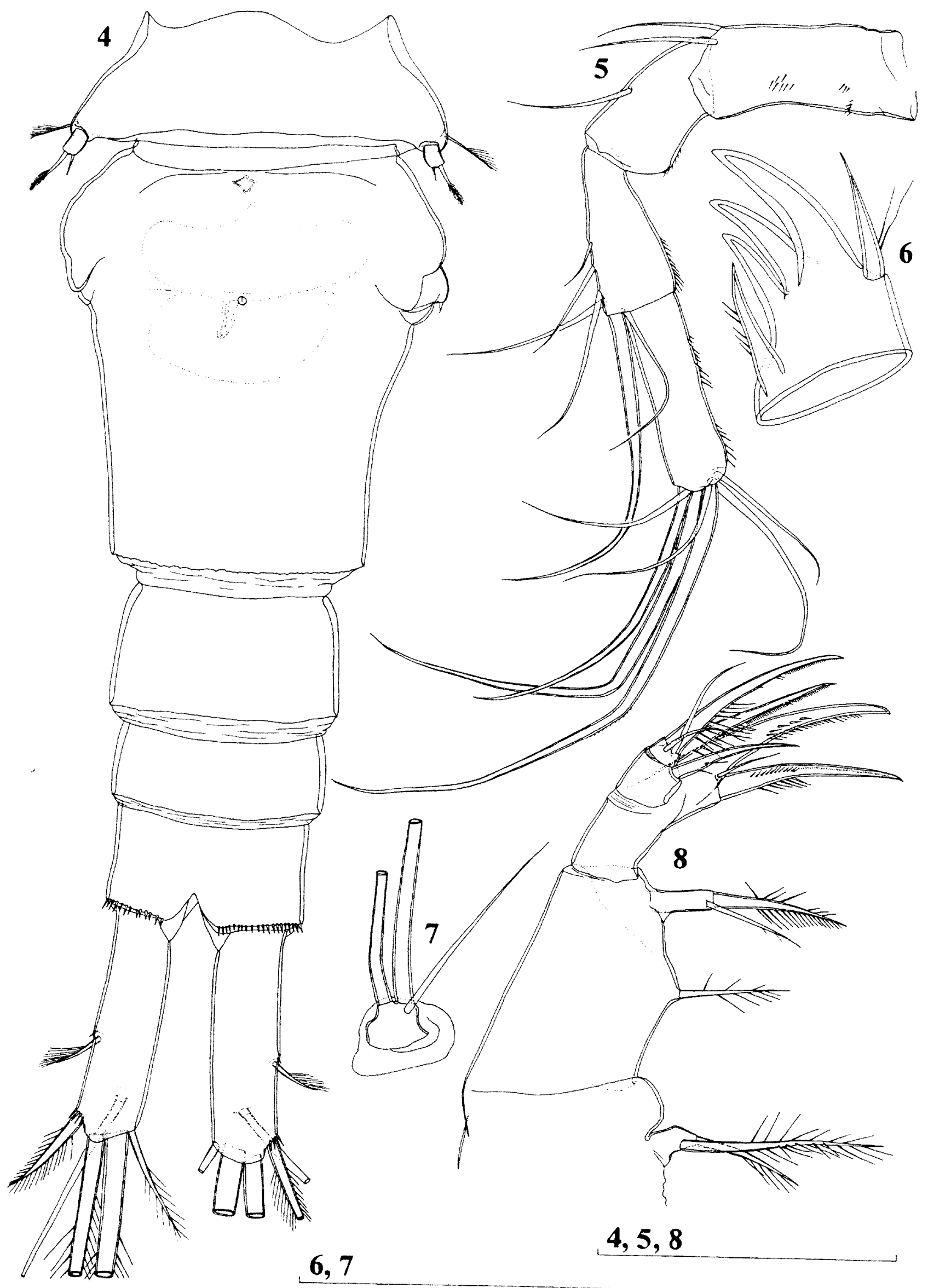

Figures 4-8 Metacyclops kimberleyi sp. nov., holotype (female): 4 - urosome, ventral view; 5 - antenna; 6 - maxillula, arthrite of praecoxa; 7 - mandibular palp; 8 - maxilla. Scales $=0.1 \mathrm{~mm}$. 


\section{Paratypes}

Westem Australia, Kimberley, Argyle Diamond Mine, groundwater monitoring bore 29D, $16^{\circ} 41^{\prime} 37^{\prime \prime} \mathrm{S}, 128^{\circ} 27^{\prime} 11^{\prime \prime} \mathrm{E}, 10$ October 2002 , leg. W. F. Humphreys and R. Webb (BES 9693): one female on SEM stub, couted in gold (WAM C28630) + four copepodids in alcohol (WAM C28631).

\section{Other naterial}

Western Australia, Kimberley, Argyle Diamond Mine, groundwater monitoring bore 305 , $16^{\circ} 41^{\prime} 22^{\prime \prime} \mathrm{S}, 128^{\circ} 27^{\prime} 05^{\prime \prime} \mathrm{E}, 10$ October 2002, leg. W. F. Humphreys and R. Webb (BES 9699): three copepodids in alcohol (WAM C28632).

\section{Description}

Female (holotype). Body length, excluding caudal setae, $0.862 \mathrm{~mm}$. Habitus (Figure 1) robust, with prosome/urosome ratio 1.4 and greatest width at posterior part of cephalothorax. Body length/width ratio about 2.8; cephalothorax almost 2.5 times as wide as genital double-somite. Rostral expansion well developed. Free pedigerous somites without particular expansions laterally. Colour of preserved specimen yellowish. Nauplius eye not visible. Rostrum well developed, membranous, broadly rounded and furnished with two large sensillae. Cephalothorax somewhat longer than wide; represents $40 \%$ of total body length. Surface of cephalothorax shield with few large sensillae, smooth (without minute cuticular pits). Whole body very smooth, with only a few sensillae on prosomites. Hyaline fringes of prosomites narrow and smooth. Fifth pedigerous somite ornamented with 2 dorsal large sensillae and 2 lateral ones; hyaline fringe smooth both dorsally and ventrally (Figures 2, 4 and 11). Genital double-somite slightly longer than wide (ventral view), ornamented with 2 large lateral sensillae; hyaline fringe finely serrated both ventrally and dorsally. Copulatory pore very small, rounded, situated at distal end of first third of somite length; copulatory duct narrow, sclerotized and siphon-shaped. Seminal receptacle relatively large, represents $45 \%$ of double-somite's length, with clearly divided anterior and posterior expansions; anterior expansion about 1.2 times as long as posterior one (Figures 4 and 11). Ovipores situated dorsolaterally, covered with reduced sixth legs. Third and fourth urosomal somites unornamented, with irregularly serrated fringes both ventrally and dorsally; third somite about 1.6 times as long as fourth somite. Anal somite with smooth, straight, anal operculum, which somewhat produced posteriorly, but not reaching posterior margin of somite; ornamented with 2 large sensillae dorsally and transverse row of spinules on posterior margin (Figures 9 and 15). Anal sinus smooth.

Caudal rami (Figures 4, 9 and 15) slightly divergent, with space between them of about 0.6 of
1 ramus width, and 3.4 times as long as wide; ornamented with few spinules at base of lateral and outermost apical setae, smooth. Dorsal seta very long, about 2.1 times as long as ramus, inserted at $5 / 6$ of ramus length, uniarticulate at base and bipinnate at distal part. Lateral seta arising at $3 / 5$ of ramus length, shorter than ramus width. Outermost apical seta very stout, spiniform, about 0.46 times as long as ramus, bipinnate. Innermost apical seta about 0.26 times as long as dorsal one, and almost 1.2 times as long as outermost apical seta. Principal apical setae without visible braking planes; inner seta about 1.5 times as long as outer one, and 0.34 times as long as body length.

Antennula (Figure 16) 11-segmented, almost reaching posterior margin of cephalothorax, with slender aesthetascs on eighth and eleventh segments and setal formula as follows: 7.4.6.2.2.2.3.2.2.3.7. Just one seta on fourth segment articulating on basal part. One seta on fifth segment spiniform and very short. Just 12 setae (30\%) pinnate at distal part (mostly longer and stronger setae); other setae smooth. First segment ornamented with arched row of spinules on anterior surface; other segments with no ornamentation visible. Length ratio of antennular segments, from proximal end and along caudal margins, $1: 0.3: 0.5: 0.2: 0.15: 0.4: 0.9: 0.7: 0.3:$ $0.4: 0.5$.

Antenna (Figure 5) 4-segmented, comprising relatively large coxobasis and 3 -segmented endopod; ornamented with longitudinal rows of minute spinules along posterior margin of endopodal segments. Coxobasis about 2.3 times as long as wide, ornamented with three small groups of minute spinules, armed with 2 smooth setae at distal inner corner; seta representing exopod absent. First endopodal segment armed with 1 smooth seta. Second endopodal segment about twice as long as wide, armed with 6 setae (4 lateral, 1 subapical, and 1 apical). Third endopodal segment about 3 times as long as wide, armed with 7 apical setae. All setae smooth, except longest apical one, which ornamented with short row of minute spinules at midlength.

Labrum (Figure 12) trapezoidal, ornamented with 2 bunches of nearly 30 long and slender spinules on ventral surface. Cutting edge straight, with 13 relatively large teeth between produced sharp lateral corners. No other ornamentation visible.

Mandibula (Figures 7, 10 and 18) with small but distinct palp, armed with 2 very long, finely plumed setae and 1 short, smooth, seta on distal end. Coxal gnathobase cutting edge with very strong teeth and 2 outermost pinnate setae; one seta somewhat longer than neighboring tooth, other much shorter.

Maxillula (Figures 6 and 19) composed of well developed praecoxa and 2-segmented palp. Arthrite 


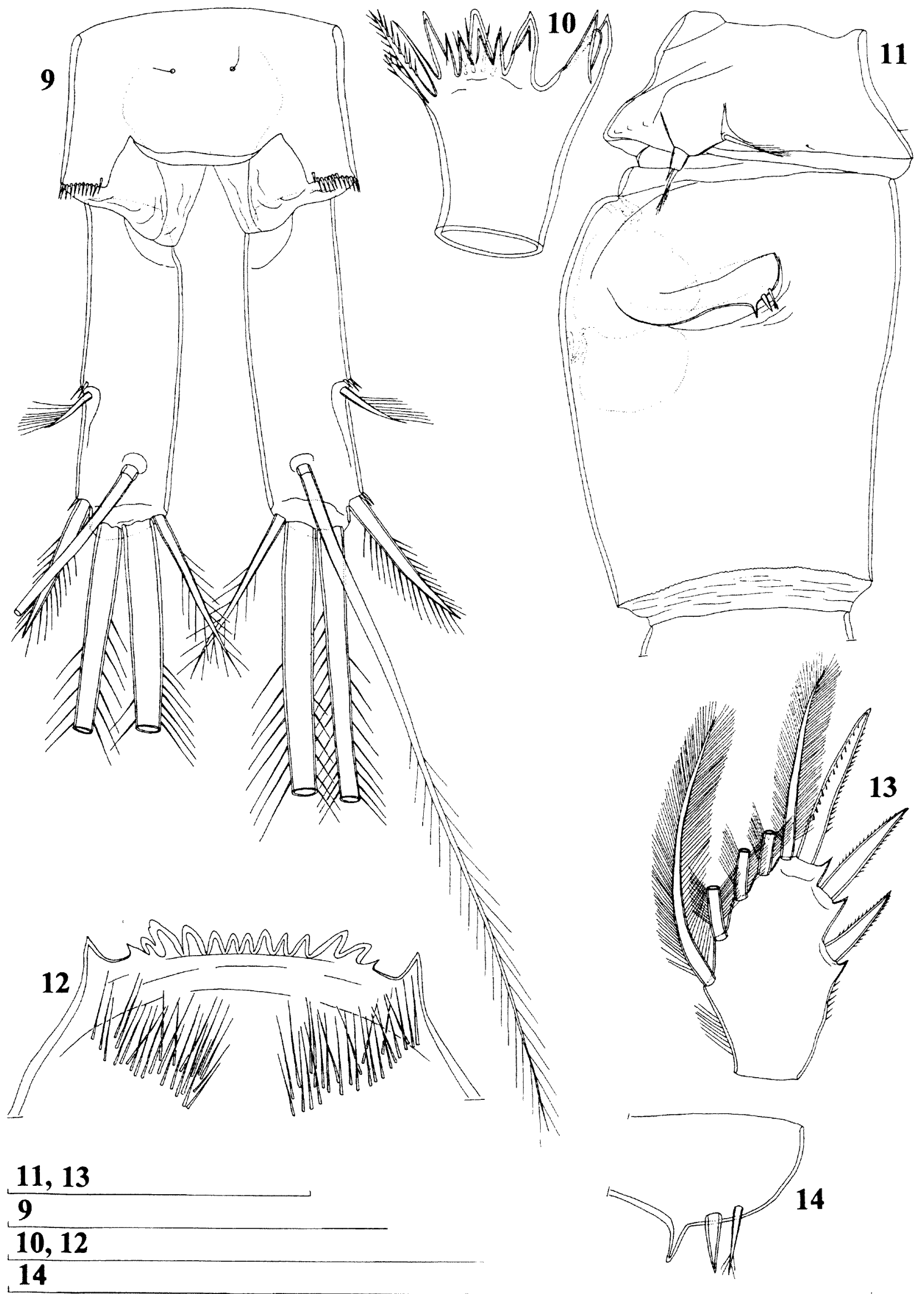

Figures 9-14 Metacyclops kimberleyi sp. nov., holotype (female): 9 - anal somite and caudal rami, dorsal view; 10 mandibula; 11 - fifth pedigerous and genital double-somite, lateral view; 12 - labrum; 13 - second exopodal segment of second swimming leg; $14-$ sixth leg, lateral view. Scales $=0.1 \mathrm{~mm}$. 


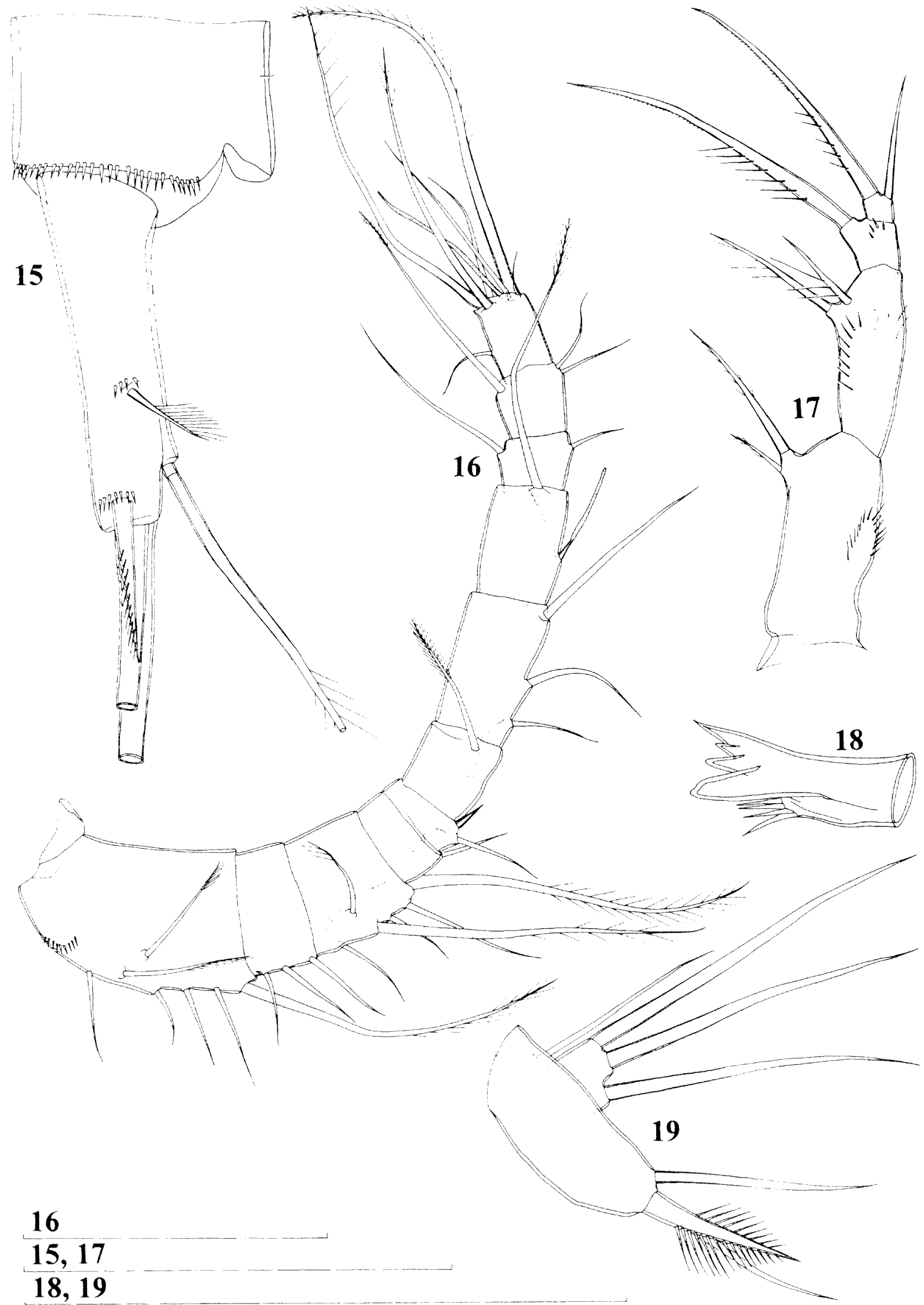

Figures 15-19 Metacyclops kimberleyi sp. nov., holotype (female): 15- anal somite and left caudal ramus, lateral view; 16 - antennula; 17 - maxilliped; 18 - mandibula, coxal gnathobase; 19 - maxillular palp. Scales $=0.1 \mathrm{~mm}$. 


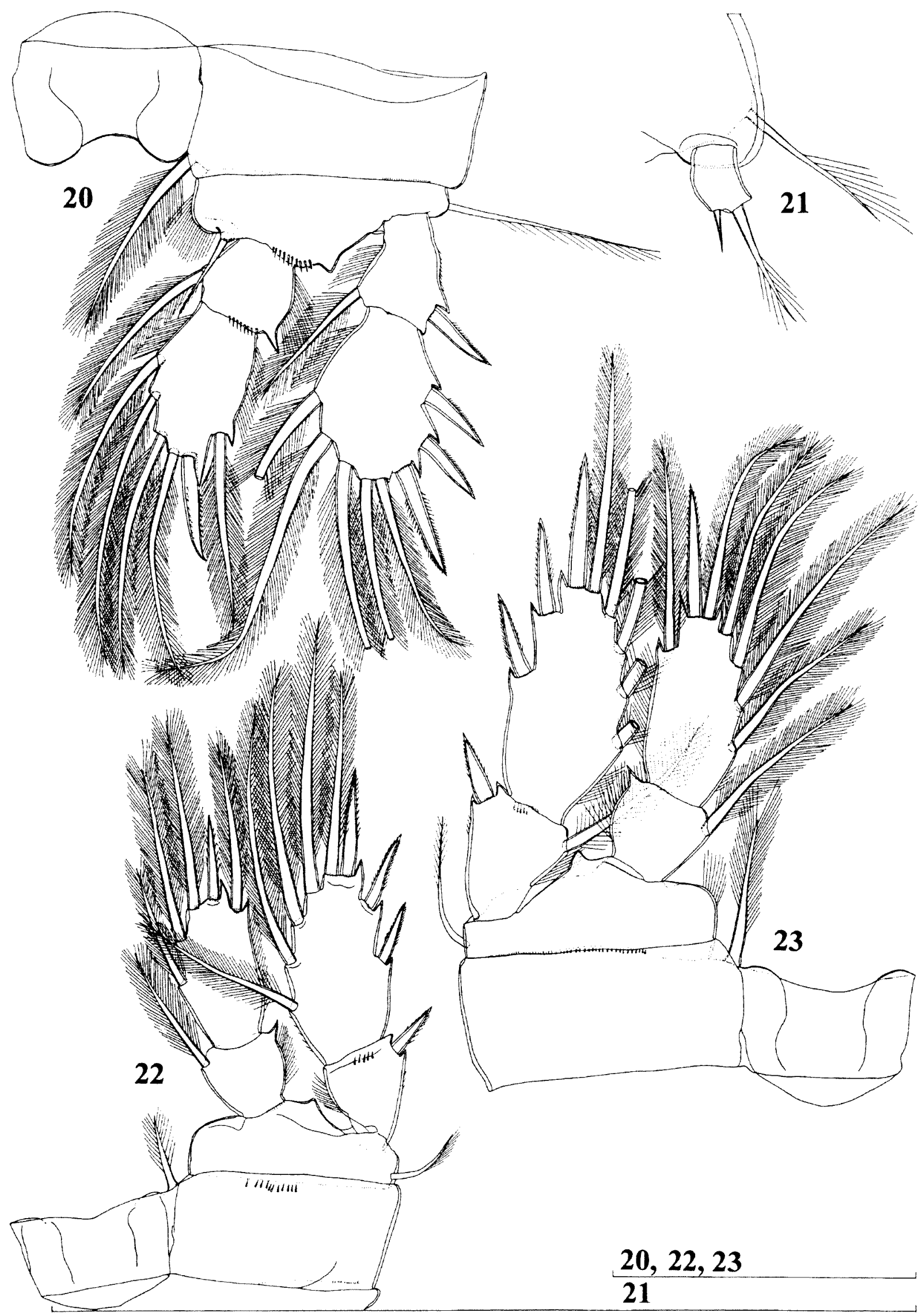

Figures 20-23 Metacyclops kimberleyi sp. nov., holotype (female): 20 - first swimming leg; 21 - fifth leg; 22 - fourth swimming leg; 23 - third swimming leg. Scales $=0.1 \mathrm{~mm}$. 
of praecoxa with 4 strong apical spines; only 1 distinct and ornamented with 2 setules. Praecoxa armed with 6 armature elements along inner margin, longest one pinnate. Palp with distinct endopod, which bearing 2 apical and 1 lateral smooth setae, and armed laterally with 1 exopodal smooth seta and apically with 2 slender and smooth setae and 1 robust, strongly bipinnate, spine. Margin between endopod and distal part of basis straight.

Maxilla (Figure 8) enormous comparing with other mouth appendages, 5-segmented, but praecoxa fused to coxa on posterior surface, and also partly on anterior surface. No omamentation visible. Proximal endite of praecoxa elongate, slender, armed with 2 pinnate setae; distal endite short, unarmed. Proximal endite of coxa with 1 bipinnate seta; distal endite highly mobile, elongate, and armed apically with 1 slender and 1 strong and bipinnate seta. Basis expanded into not very robust claw, ornamented with longitudinal row of strong spinules along concave margin (all spinules of about same length), and armed with 2 setae; strong seta as long as claw, pinnate. Endopod 2segmented; proximal segment armed with 2 robust setae; distal segment with 1 robust and pinnate apical seta and 2 slender and smooth setae. Longest seta on distal endopodal segment slightly longer than strong seta on basis.

Maxilliped (Figure 17) 4-segmented, composed of syncoxa, basis and 2-segmented endopod. Syncoxa ornamented with arched row of spinules on proximal part of outer margin, armed with 2 bipinnate setae; distal seta almost 2.5 times as long as proximal one. Basis 2.3 times as long as wide, ormamented with 1 longitudinal and 1 transverse row of long spinules, and armed with 2 strong unipinnate setae. First endopodal segment ornamented with 4 small spinules, armed with 1 very strong, spiniform and unipinnate, seta. Second endopodal segment without any ornamentation, armed with only 2 apical setae; inner seta twice as long as outer one and 0.8 times as long as seta on first endopodal segment.

All swimming legs with 2-segmented exopods and endopods (Figures 13, 20, 22 and 23). Swimming legs armature formula as follows (legend: inner/outer spine or seta; inner/terminal/ outer):

\begin{tabular}{lllll} 
& \multicolumn{2}{l}{ Exopod } & \multicolumn{2}{l}{ Endopod } \\
Segments & 1 & 2 & 1 & 2 \\
First leg & $1 / 1$ & $3 / 2 / 3$ & $1 / 0$ & $3 / 2 / 1$ \\
Second leg & $1 / 1$ & $4 / 2 / 2$ & $1 / 0$ & $4 / 2 / 1$ \\
Third leg & $1 / 1$ & $4 / 2 / 2$ & $1 / 0$ & $4 / 2 / 1$ \\
Fourth leg & $0 / 1$ & $4 / 2 / 2$ & $1 / 0$ & $3 / 1 / 1$
\end{tabular}

Second exopodal segment spine formula: 3.3.3.3. Intercoxal sclerite of all swimming legs with concave distal margins, and without any ornamentation. Coxae of all swimming legs ornamented with row of spinules along posterior margin (those on fourth leg largest) and armed with plumose seta on distal inner corner (that on fist leg longest, on fourth leg shortest). Relatively slender spine inserted at inner corner of basis of first leg reaching somewhat beyond posterior margin of first endopodal segment. Outer seta on basis of first swimming leg long; those on other legs much shorter; just seta on second leg basis smooth, other setae unipinnate at distal end. All setae on endopods and exopods slender and plumose; no modified setae observed. Second endopodal segment of fourth swimming leg about 1.8 times as long as wide; only apical spine almost twice as short as segment (Figure 22).

Fifth leg (Figures 2, 11 and 21) with basal segment completely fused to somite, with remnant of ancestral separation visible in dorsal view; outer basal seta inserted dorsally on somite and unipinnate at distal part. Distal segment about 1.4 times as long as wide, armed with apical outer seta and subapical inner spine; without any ornamentation. Apical seta on distal segment bipinnate at distal end, about 1.8 times as long as segment, 3 times as long as spine, and about 0.7 times as long as basal seta. Spine on distal segment smooth and 0.6 times as long as segment.

Sixth leg (Figures 2, 11 and 14) indistinct, very small cuticular plate, armed with 2 almost equal, smooth, spines, and 1 slightly longer and bipinnate seta. Median spine distinct, other one completely fused to leg.

Male (allotype). Body length, excluding caudal setae, $0.712 \mathrm{~mm}$. Habitus (Figure 27) slender, with prosome/urosome ratio 1.7 and greatest width at posterior end of cephalothorax. Body length/width ratio about 2.8 ; cephalothorax about 2.4 times as wide as genital somite. Rostral expansion well developed. Cephalothorax slightly longer than its greatest width; represents $39 \%$ of total body length. Ornamentation of prosomal somites, colour, and nauplius eye similar to female. Hyaline fringe of fifth pedigerous somite smooth. Genital somite twice as wide as long, with irregularly serrated hyaline fringe dorsally. Hyaline fringes of other urosomal somites (except anal one) finely serrated both dorsally and ventrally. Anal somite ornamented with 2 large dorsal sensillae and with transverse row of spinules on posterior margin.

Caudal rami (Figure 24) parallel, with space between them less than half of 1 ramus width, and about 3.8 times as long as wide. Armature and ormamentation similar to female.

Antennula (Figures 25 and 26) 15-segmented (ancestral fifth and sixth, as well as sixteenth and seventeenth, segments fused), geniculate, with geniculation between thirteenth and fourteenth segments, longer than cephalothorax. First segment with 3 aesthetascs; 1 aesthetasc present on fourth, 


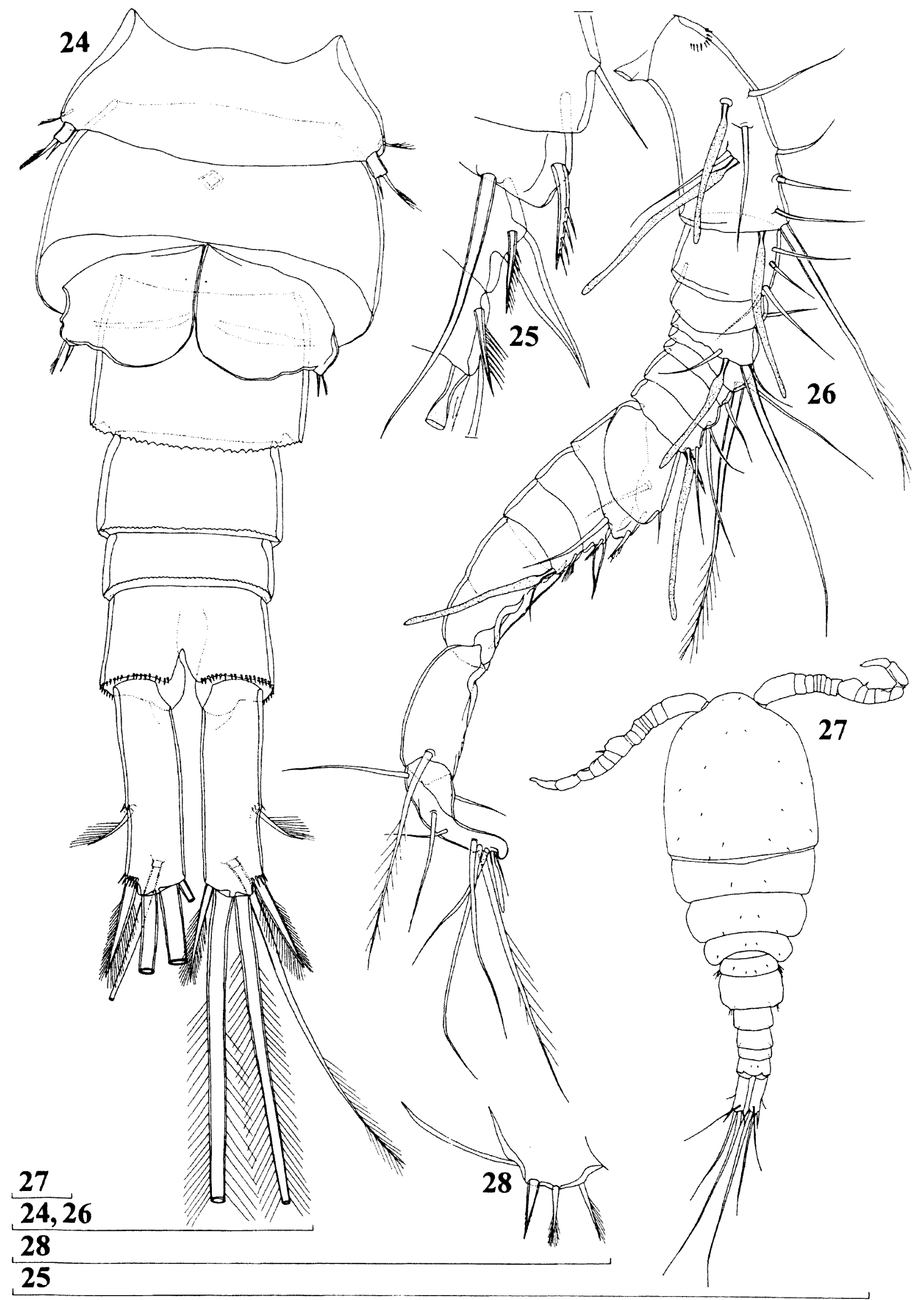

Figures 24-28 Metacyclops kimberleyi sp. nov., allotype (male): 24 - urosome, ventral view; 25 - antennula, detail; 26 -antennula; 27 - habitus, dorsal view; 28 - sixth leg, lateral view. Scales $=0.1 \mathrm{~mm}$. 
eighth, twelfth, and fifteenth segment. All aesthetascs slender and short. Setal formula as follows: 7.4.1.2.1.2.1.2.2.2.2.2.2.1.1.3.6. Many setae characteristically modified, spiniform. Part of tenth segment as distinct lobe, bearing 1 slender and 1 spiniform seta. Elements of thirteenth and fourteenth and segments typically transformed as log T-shaped plates.

Antenna, labrum, mandibula, maxillula, maxilla, maxilliped and swimming legs similar to female. Second endopodal segment of fourth swimming leg with slightly longer apical spine than in female.

Fifth leg (Figure 24) similar to female. Distal segment about 1.5 times as long as wide, armed with apical outer seta and subapical inner spine; without any ornamentation. Apical seta on distal segment bipinnate at distal end, about 1.8 times as long as segment, twice as long as spine, and as long as basal seta. Spine on distal segment smooth and slightly shorter than segment.

Sixth leg (Figure 28) simple cuticular plate, clearly divided on outer surface, armed with 1 spine and 2 pinnate setae; ornamented with single cuticular pore. Both setae and spine of about same length.

\section{Variability}

Besides the holotype and allotype only one additional adult specimen has been collected and studied (both under brightfield compound microscope and scanning electron microscope), although not dissected. That paratype female is slightly shorter than the holotype $(0.845 \mathrm{~mm})$, but without any other noticable variation.

\section{Etymology}

The name is derived from the region Kimberley (Western Australia) where the species was collected. It is to be treated as a noun in the genitive singular.

\section{Metacyclops pilbaricus sp. nov. Figures 3 and $29-44$}

\section{Material Examined}

\section{Holotype}

Female (WAM C28633), Western Australia, Pilbara, Newman Borefield, groundwater

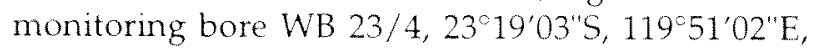
23 July 1997, leg. W. F. Humphreys and S. M. Eberhard (BES 4823 and 4829): dissected on two slides.

\section{Paratypes}

Western Australia, Pilbara, Newman Borefield,

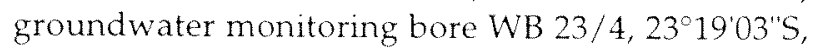
$119^{\circ} 51^{\prime} 02^{\prime \prime} \mathrm{E}, 23 \mathrm{July} 1997, \mathrm{leg}$. W. F. Humphreys and S. M. Eberhard (BES 4823 and 4829): two copepodids in alcohol (WAM C28634).

\section{Description}

Female (holotype). Body length, excluding caudal setae, $0.7 \mathrm{~mm}$. Habitus (Figure 3 ) very characteristic, spindle-shaped, with prosome/urosome ratio 1.5 and greatest width at middle of cephalothorax length. Body length/width ratio about 3; cephalothorax about 2.1 times as wide as genital double-somite. Rostral expansion well developed. Free pedigerous somites without particular expansions laterally. Preserved specimen colourless. Nauplius eye not visible. Rostrum well developed, membranous, broadly rounded and furnished with two large sensillae. Cephalothorax slightly longer than wide; represents $34 \%$ of total body length. Surface of cephalothorax shield smooth, ornamented only with many large sensillae. Whole body smooth, without any cuticular pits. Hyaline fringes of prosomites narrow and smooth. Fifth pedigerous somite ornamented with 4 dorsal large sensillae; hyaline fringe smooth both dorsally and ventrally (Figure 30). Genital doublesomite as long as its greatest width (ventral view), ornamented with 2 large dorsal sensillae; hyaline fringe serrated dorsally and laterally, but smooth ventrally. Copulatory pore small, squeezed and arched, situated at 2/5 of somite length; copulatory duct straight, short, well sclerotized and oriented anteriorly. Seminal receptacle relatively short but broad, represents 30\% of double-somite's length, with clearly divided anterior and posterior expansions; posterior expansion approximately 1.5 times as long as anterior one (Figure 30). Ovipores situated dorsolaterally, covered with reduced sixth legs. Third and fourth urosomal somites unornamented and with smooth fringes both ventrally and dorsally; third somite about 1.5 times as long as fourth one. Anal somite with smooth, convex, anal operculum, which somewhat produced posteriorly, but not reaching posterior margin of somite; ornamented with 2 large sensillae dorsally and transverse row of small spinules on posterior margin (Figure 35). Anal sinus smooth.

Caudal rami (Figures 30 and 35) parallel, with space between them less than half of 1 ramus width, and 2.6 times as long as wide; ornamented only with few minute spinules at base of lateral and outermost apical setae. Dorsal seta relatively short, about as long as ramus, inserted at $3 / 4$ of ramus length, uniarticulate at base and pinnate at distal part. Lateral seta arising at midlength of ramus, shorter than ramus width. Outermost apical seta stout, spiniform, about 0.7 times as long as ramus, bipinnate. Innermost apical seta about 0.7 times as long as dorsal one, and 0.8 times as long as outermost apical seta. Principal apical setae without braking planes; inner seta about 2.2 times as long as outer one, and 0.37 times as long as body length. Inner principal apical seta on right ramus with abnormality, probably as consequence of damage during postembryonic development. 


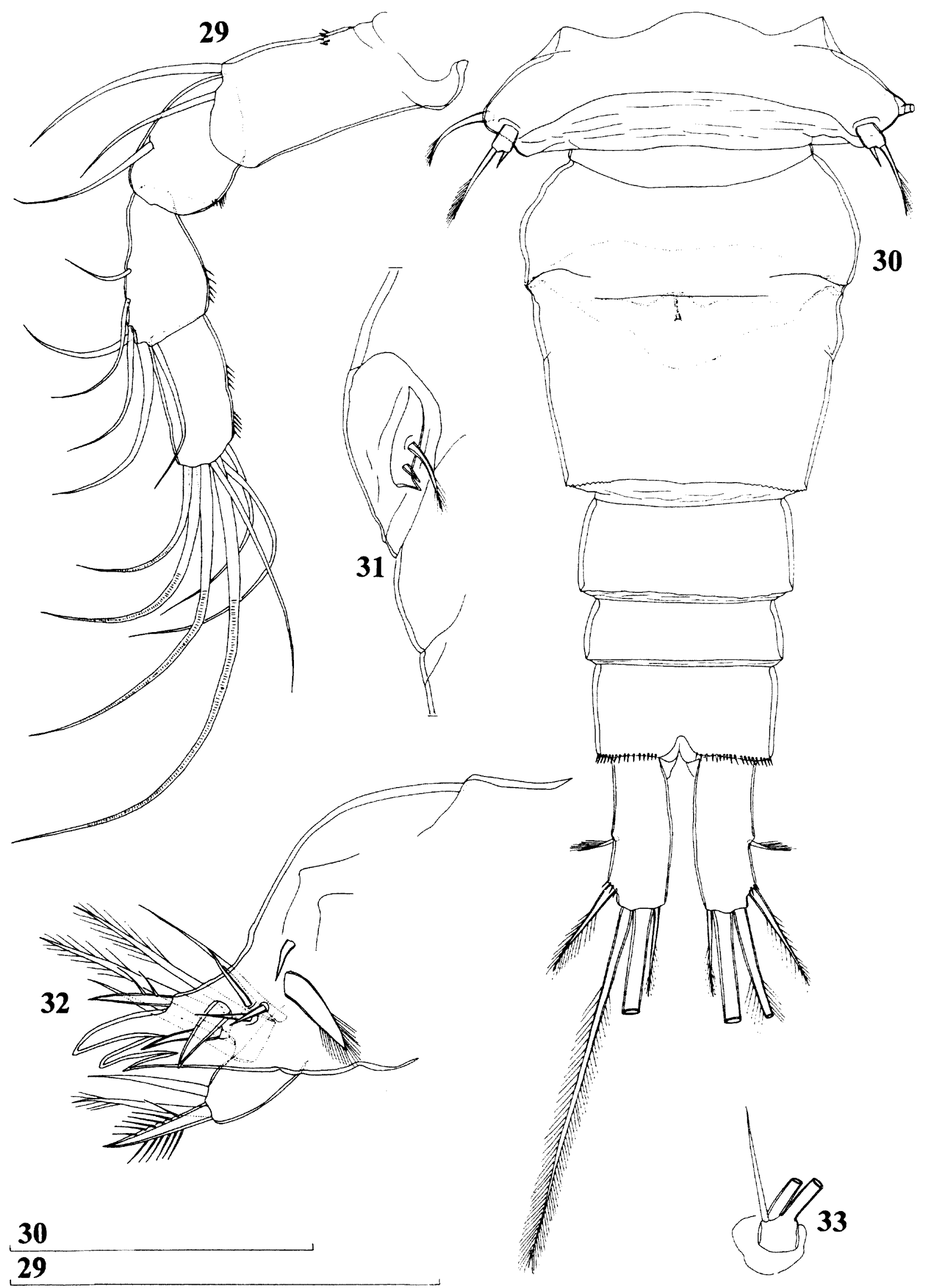

\section{$31,32,33$}

Figures 29-33 Metacyclops pilbaricus sp. nov., holotype (female): 29 - antenna; 30 - urosome, ventral view; 31 - sixth leg, dorsal view; 32 - maxillula; 33 - mandibular palp. Scales $=0.1 \mathrm{~mm}$. 
Antennula (Figure 34) 11-segmented, not reaching posterior margin of cephalothorax, with slender aesthetascs on eighth and eleventh segments and setal formula as follows: $7 \cdot 4 \cdot 6 \cdot 2 \cdot 2 \cdot 2 \cdot 3 \cdot 2.2 .3 .7$. One apical seta on eleventh segment articulating on basal part. One seta on fifth segment spiniform and very short. Just 2 setae on first segment, 1 on third, 1 on tenth and 3 setae on eleventh segment pinnate at distal part; all other setae smooth. First segment ornamented with short semitransverse row of spinules on anterior surface; other segments with no ornamentation visible, except cuticular pits. Length ratio of antennular segments, from proximal end and along caudal margins, $1: 0.4: 0.6: 0.4: 0.2$ $0.6: 1: 0.9: 0.5: 0.7: 0.8$.

Antenna (Figure 29) 4-segmented, comprising short coxobasis and 3-segmented endopod; ornamented with longitudinal rows of minute spinules on endopodal segments. Coxobasis relatively long, ornamented also with few spinules anterior surface, armed with 2 smooth setae at distal inner corner (without seta representing exopod). First endopodal segment armed with 1 smooth seta. Second endopodal segment about 1.5 times as long as wide, armed with 6 setae (4 lateral, 1 subapical, and 1 apical). Third endopodal segment twice as long as wide, armed with 7 apical setae. All setae smooth.

Labrum (Figure 36) trapezoidal, ornamented with 2 bunches of 14 long and slender spinules on ventral surface. Cutting edge straight, with 12 relatively strong and blunt teeth between produced sharp lateral corners. No other ornamentation visible.

Mandibula (Figure 33) with small but distinct palp, armed with 2 very long, finely plumed setae and 1 short, smooth, seta on distal end. Coxal gnathobase cutting edge with very strong teeth and outermost pinnate seta, which shorter than short seta on palp.

Maxillula (Figures 32) composed of well developed praecoxa and 2-segmented palp. Arthrite of praecoxa with 4 strong apical spines; only 1 distinct and ornamented with 2 setules. Praecoxa armed with 7 armature elements along inner margin, longest one pinnate. Palp with completely divided endopod, which bearing 2 apical pinnate and 1 lateral smooth setae, and armed laterally with 1 exopodal smooth seta and apically with 2 slender setae ( 1 pinnate, other smooth) and 1 robust, strongly bipinnate, spine. Margin between endopod and distal part of basis without particular expansions.

Maxilla (Figure 37) unornamented, 5-segmented, but praecoxa fused to coxa on posterior surface, and also partly on anterior surface. Proximal endite of praecoxa elongate, armed with 2 pinnate setae, distal endite small, unarmed. Proximal endite of coxa with 1 strong, bipinnate, seta; distal endite highly mobile, elongate, and armed apically with 2 subequal pinnate setae. Basis expanded into robust claw, ornamented with longitudinal row of strong spinules along concave margin (proximalmost spinules shortest), and armed with 2 setae; strong seta as long as claw, pinnate. Endopod 2segmented; proximal segment armed with 2 robust setae; distal segment with 1 robust apical seta and 2 slender subapical setae; all setae on endopod smooth. Longest seta on distal endopodal segment as long as strong seta on basis.

Maxilliped (Figure 43) 4-segmented, composed of syncoxa, basis and 2-segmented endopod. Syncoxa ornamented with arched row of spinules on proximal part of outer margin, armed with 3 setae; middle setae strongest and longest, 1.36 times as long as proximal one, and about twice as long as distal seta; distalmost seta smooth, other 2 unipinnate. Basis 1.2 times as long as wide, ornamented with 1 longitudinal and 1 transverse row of long spinules on inner side and 1 row of spinules on outer distal corner; armed with 2 strong pinnate setae. First endopodal segment ornamented with transverse row of spinules along posterior margin; armed with 1 strong spiniform seta. Second endopodal segment without any ornamentation, armed with 2 smooth and 1 pinnate spiniform seta. Strongest seta on second endopodal segment about 1.2 times as long as seta on first endopodal segment.

All swimming legs with 2-segmented exopods and endopods (Figures 39, 40,41 and 42). Swimming legs armature formula as follows (legend: inner/outer spine or seta; inner/terminal/ outer):

\begin{tabular}{lllll} 
& \multicolumn{2}{l}{ Exopod } & \multicolumn{2}{l}{ Endopod } \\
Segments & 1 & 2 & 1 & 2 \\
First leg & $1 / 1$ & $3 / 2 / 3$ & $1 / 0$ & $3 / 2 / 1$ \\
Second leg & $1 / 1$ & $4 / 2 / 2$ & $1 / 0$ & $4 / 2 / 1$ \\
Third leg & $1 / 1$ & $4 / 2 / 2$ & $1 / 0$ & $4 / 2 / 1$ \\
Fourth leg & $0 / 1$ & $4 / 2 / 2$ & $1 / 0$ & $3 / 1 / 1$
\end{tabular}

Second exopodal segment spine formula: 3.3.3.3. Intercoxal sclerite of all swimming legs with deeply concave distal margins, and without any ornamentation. Coxa of fourth swimming leg ornamented with 2 row of spinules; coxae of other swimming legs with only 1 row of spinules each. All coxae with long and plumose seta on distal inner corner, except on fourth leg, where that seta is smooth and spiniform. Spine inserted at inner corner of basis of first leg reaching distal margin of second endopodal segment. Outer seta on basis of first swimming leg very long; those on other legs much shorter; just seta on second leg basis smooth, other setae pinnate at distal end. All setae on endopods and exopods slender and plumose; no modified setae observed. Second endopodal segment of fourth swimming leg about 1.6 times as long as wide; only apical spine about 0.85 times as long as segment (Figure 41). 


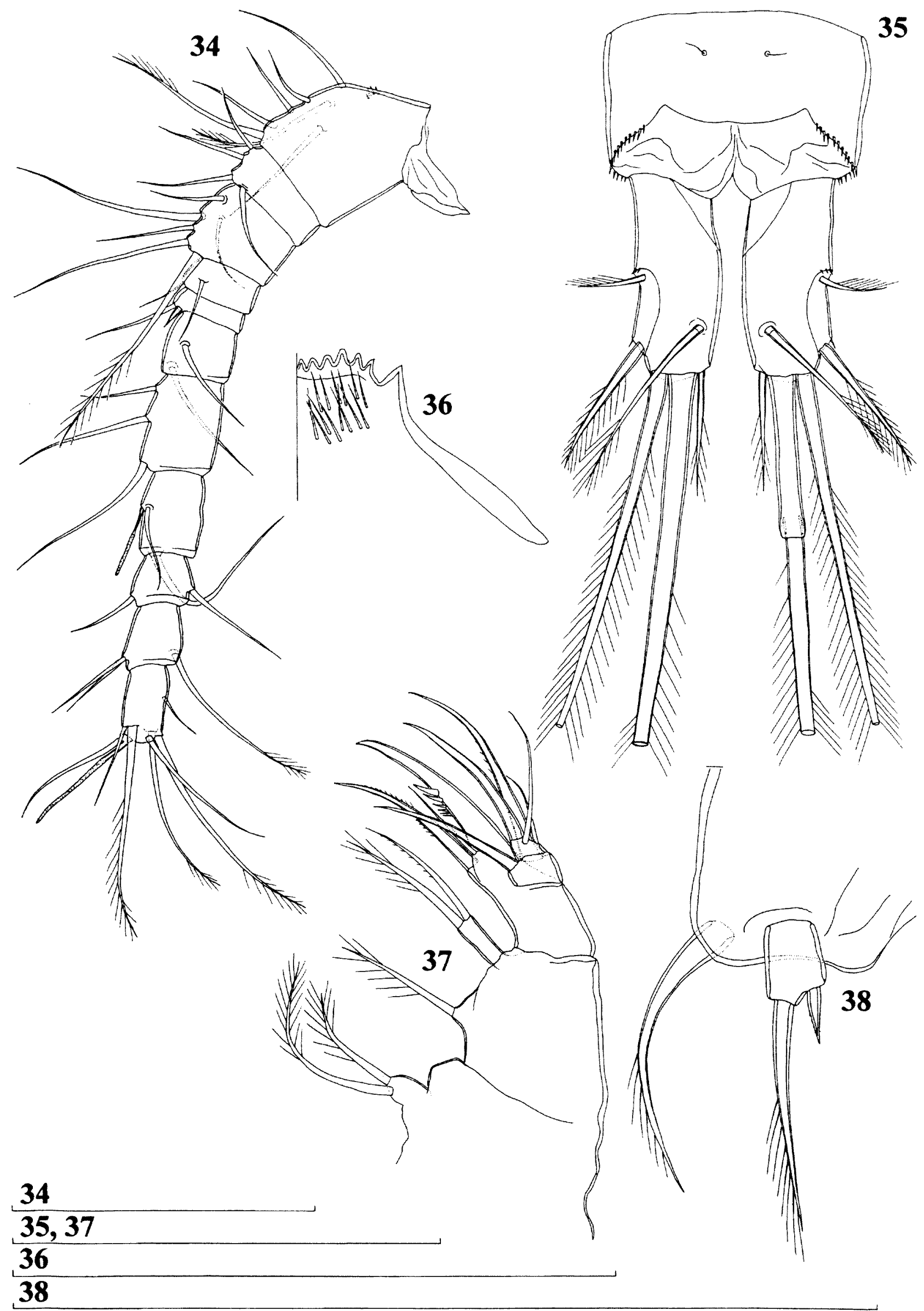

Figures 34-38 Metacyclops pilbaricus sp. nov., holotype (female): 34 - antennula; 35 - anal somite and caudal rami, dorsal view; 36 - labrum, left half; 37 - maxilla; 38 - fifth leg, ventral view. Scales $=0.1 \mathrm{~mm}$. 

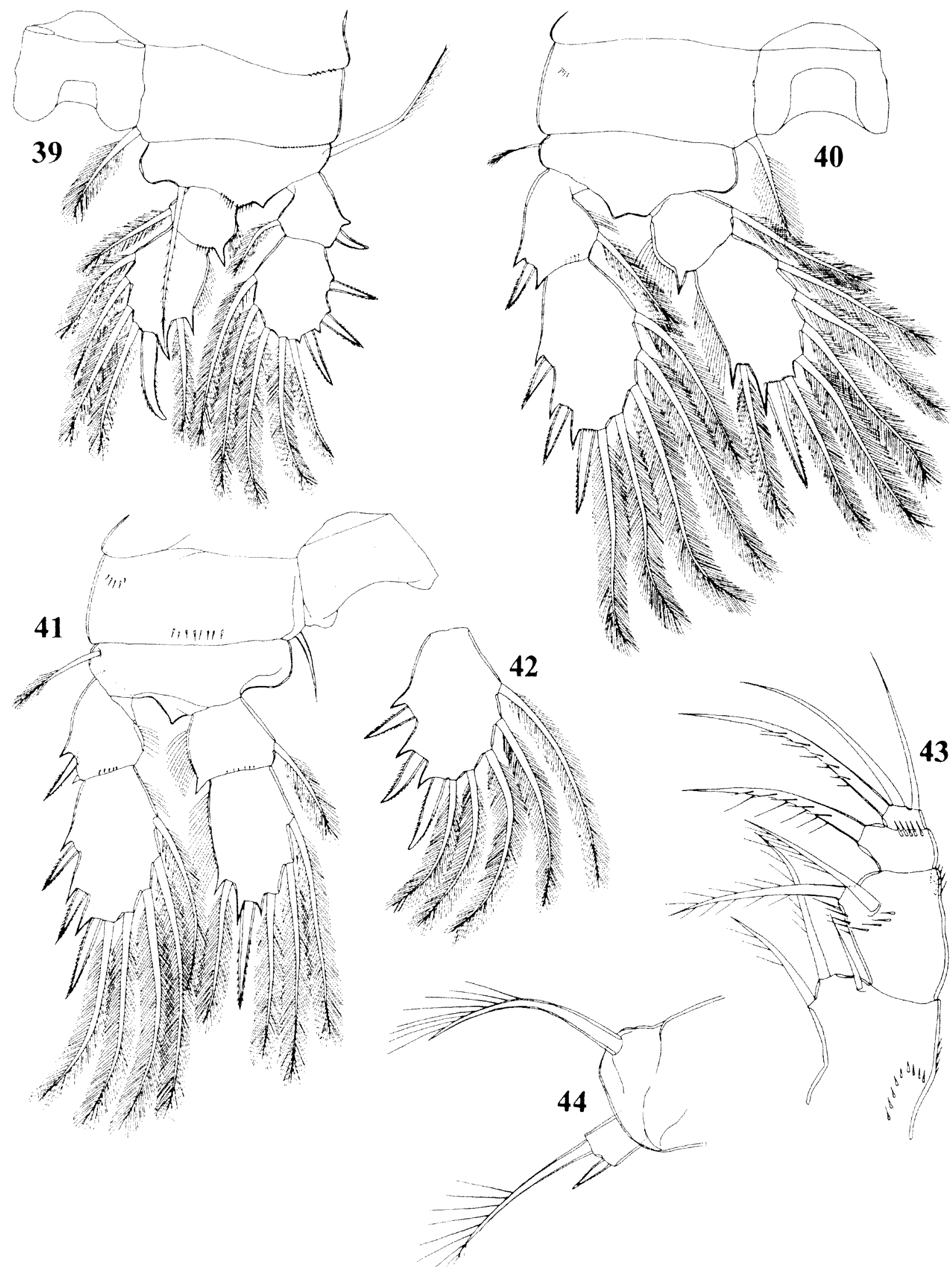

\section{$39,40,41,42$}

\section{3,44}

Figures 39-44 Mctacyclops pilbaricus sp. nov, holotype (female): 39 - first swimming leg; 40 - third swimming leg; 41 fourth swimming leg; 42 - second exopodal segment of second swimming leg; 43 - maxilliped; 44 - left fifth Jeg, dorsal view. Scales $=0.1 \mathrm{~mm}$. 


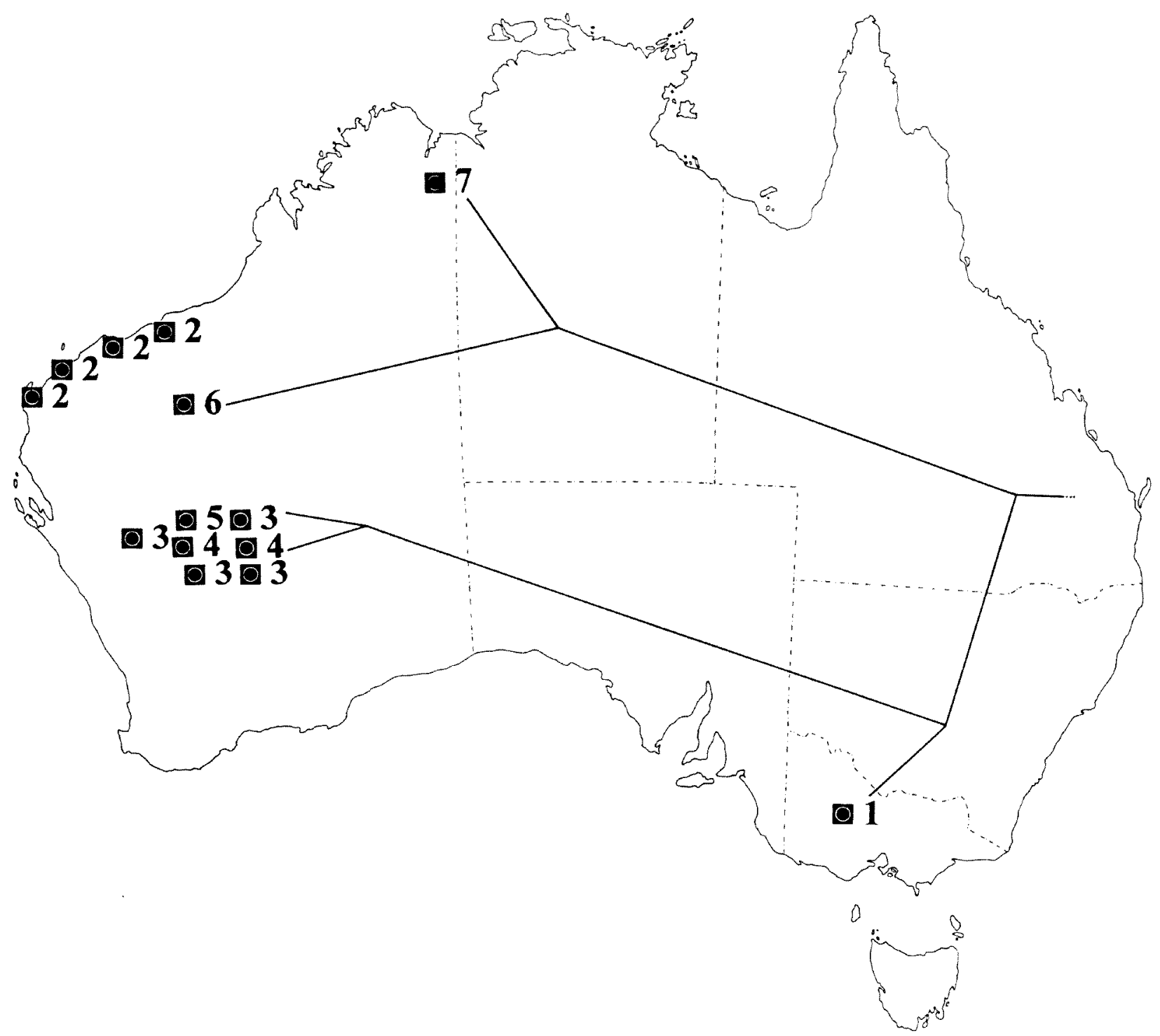

Figure 45 Distribution of the Australian representatives of the genus Metacyclops, with the proposed phyletic three of the "trispinosus"-group: $1-$ M. arnaudi (Sars, 1908); 2 - M. mortoni Pesce, De Laurentiis and Humphreys, 1996; 3 - M. laurentiisae Karanovic, 2004; 4-M. pilanus Karanovic, 2004; 5 - M. superincidentis Karanovic, 2004; $6-$ M. pilbaricus sp. nov.; $7-M$. kimberleyi sp. nov. Note: one dot sometimes represents more than one locality.

Fifth leg (Figures 30, 38 and 44) with basal segment completely fused to somite, with remnant of ancestral separation visible in dorsal view; outer basal seta inserted dorsally on somite and unipinnate at distal part. Distal segment about 1.4 times as long as wide, armed with apical outer seta and subapical inner spine; without any ornamentation. Apical seta on distal segment unipinnate at distal end, about 2.7 times as long as segment, 4.2 times as long as spine, and about 0.8 times as long as basal seta. Spine on distal segment strong and 0.65 times as long as segment.

Sixth leg (Figure 31) indistinct, very small cuticular plate, armed with 2 almost equal long, smooth, spines, and 1 pinnate and much longer seta. Median spine distinct, other one completely fused to leg.

Male. Unknown.

\section{Variability}

Only one female was collected and studied, and it appears to be without any significant asymmetries, apart from the abnormal inner principal apical seta on the right caudal ramus (Figure 35).

\section{Etymology}

The name is derived from the region Pilbara (Western Australia) where the species was collected. It is to be treated as a latinized adjective in the nominative singular, agreeing in gender with the masculine generic name.

\section{DISCUSSION}

About 60 different species and subspecies are presently known to be members of the genus 

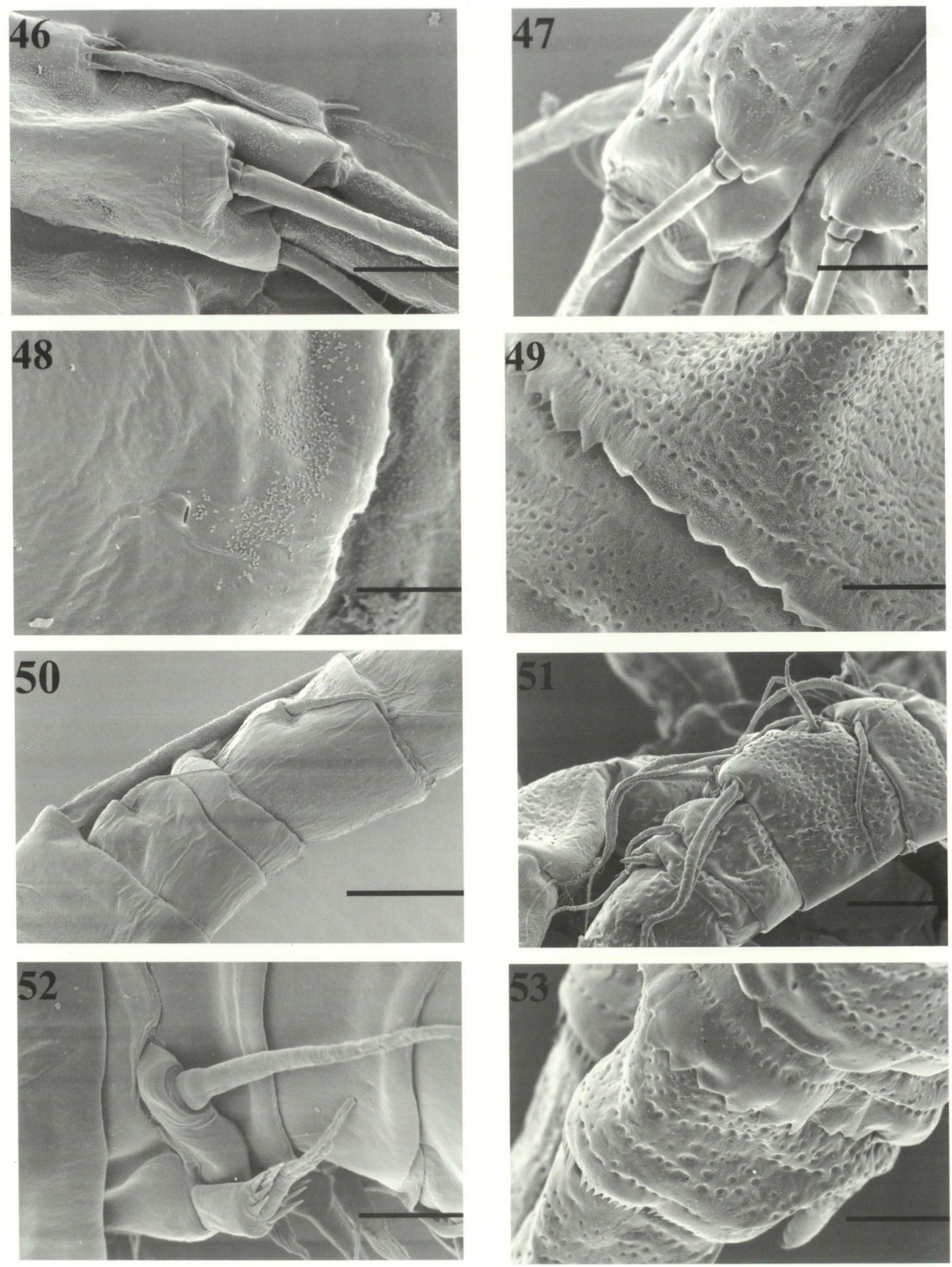

Figures 46-53 Scanning electron micrographs of two Australian Metacyclops: $46-M$. kimberleyi, female, right caudal ramus dorsally $($ scale $=11 \mu \mathrm{m}) ; 47-M$. laurentiisae, female, caudal rami dorsally $($ scale $=9 \mu \mathrm{m}) ; 48-M$. kimberleyi, female, genital double-somite, posterior margin dorsally (scale $=6 \mu \mathrm{m}) ; 49-M$. laurentiisae, female, genital double-somite, posterior margin dorsally (scale $=14 \mu \mathrm{m}) ; 50-M$. kimberleyi, female, part of antennula $($ scale $=17 \mu \mathrm{m}) ; 51-M$. laurentiisae, female, part of antennula $(\mathrm{scale}=21 \mu \mathrm{m}) ; 52-M$. laurentiisae, male, part of antennula $($ scale $=6 \mu \mathrm{m}) ; 53-$ M. laurentiisae, female, anal somite laterally $(\mathrm{scale}=14 \mu \mathrm{m})$. 

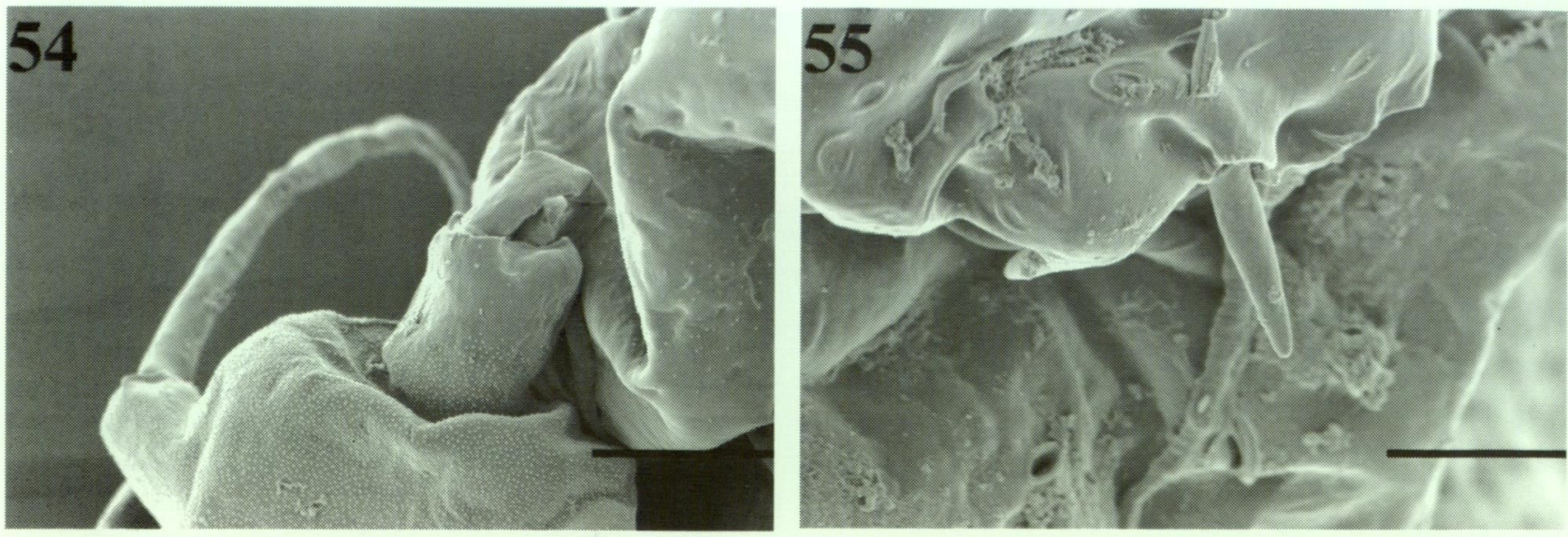

Figures 54-55 Scanning electron micrographs of Metacyclops laurentiisae: $54-$ female, fifth leg ventrally $($ scale $=10 \mu \mathrm{m})$; $55-$ female, sixth leg laterally $($ scale $=4.3 \mu \mathrm{m})$.

Metacyclops, but the real systematic position for many of those remains elusive owing to the standards of description at the time they were described (Karanovic, 2004). Many morphological features within the genus are extremely different, which raises the question as to its monophyly and validity. The antennula, for example, can be composed of nine, ten, 11,12 , or even 17 segments (although in a majority of species it is composed of 11 or 12 segments), and second endopodal segment of the fourth swimming leg can be armed apically with one or two spines, or even with just one seta, or one seta and one spine. The shape of the fifth leg also differs markedly between species, but because this appendage is very small and difficult to describe it has often been underused in species descriptions, despite its general shape being one of the main generic features (Figure 54). It is highly possible that a more detailed examination of the fifth leg, along with many other currently neglected characters, will result in splitting the genus Metacyclops into several different genera. Fiers (2001) took an initial step it that direction, when he transferred two Australian species into a separate new genus. Recently I have established a new genus (Karanovic, 2004) to accommodate another Australian species: M. fiersi De Laurentiis, Pesce and Humphreys, 2001. In contrast Plesa (1981) attempted to unite the three genera Apocyclops Lindberg, 1942, Psammophilocyclops Fryer, 1956, and Metacyclops Kiefer, 1927, as subgenera of the genus Metacyclops, but without sufficient justification (see Reid, 1987; Karanovic, 1999). A proper revision of the genus Metacyclops, with careful reexamination (especially details of the antennulae, antennae and mouth appendages armature) and redescription of many species is certainly needed before phylogenetic studies can be conducted.

However, one group of species seems to be not only an easily recognizable morphological group, but a phyletic group as well. It has a clear Eastern
Gondwana connection (Africa, India, Australia and New Zealand) and I named it the "trispinosus"group (Karanovic, 2004) after M. trispinosus Dumont, 1981, because this species' name contains the main distinguishing character: only three spines on the second exopodal segment of all the swimming legs. Besides the African M. trispinosus, which was described by Dumont (1981), the "trispinosus"-group also includes the following five species: M. arnaudi (Sars, 1908) from Australia (Sars, 1908); M. laurentiisae Karanovic, 2004 also from Australia (Karanovic, 2004); M. margaretae (Lindberg, 1938) from India (Lindberg, 1938); $M$. monacanthus (Kiefer, 1928) from New Zealand (Kiefer, 1928); and M. pilanus Karanovic, 2004 from Australia. The new species described in the present paper also belong to this group, which means that Australia is the centre of diversity (with five out of eight species), although this could be a collecting bias. Two apical spines on the endopod of the fourth swimming leg is a symplesiomorphy of the African $M$. trispinosus and Indian M. margaretae, which also share relatively short and subequal principal apical setae on the caudal rami. Both these species are surface water inhabitants (see Lindberg, 1938; Dumont, 1981). All other species of the "trispinosus"-group have an apomorphic endopod of the fourth leg, with just one apical spine. They are all Australian species, except $M$. monacanthus which was described from the Lake Ellesmere near Christchurch in New Zealand (Kiefer, 1928). This latter species is also a surface water inhabitant and is only partially described. Unfortunately, we know nothing about its antenna or mouth appendages, although I believe they are very similar to those of M. arnaudi since Kiefer (1928) wrote: "Cyclops monacanthus nov. spec. besitzt eine auffallende, ohne Zweifel auf Verwandtschaft beruhende Ähnlichkeit mit C. arnaudi Sars". However, a detailed redescription of this species is necessary before it can be further discussed phylogenetically. 
Of the five Australian species of the "trispinosts"group, only one, $M$. arnaudi, is a surface water inhabitant. As previously mentioned, this species was described from a swamp at St. Arnaud in Victoria by Sars (1908). It is morphologically very similar, and probably phylogenetically very close, to two sympatric subterranean species from the Murchison Region: M. laurentiisae and M. pilanus. They all share a plesiomorphic antenna morphology, with the exopod present and the second endopodal segment with the full armature (nine setae). As depicted on the proposed phyletic tree for the "trispinosus"-group (Figure 45) I assume that $M$. arnaudi has separated earlier from the common ancestor than $M$. laurentiisae and $M$. pilanus, but this may not necessarily be the case and probably only an molecular analysis could give us a more accurate answer. These three species can be distinguished from each other only by details in their habitats and caudal rami shape. The two new species, on the other hand, have an antenna without an exopod and the second endopodal segment with only six setae, which is a synapomorphy that separates them at once from the three other representatives of this group in Australia. Metacyclops kimberleyi sp. nov. is distinguished from other members of the group by at least two autapomorphies: the exceptionally long dorsal seta on caudal rami (Figure 9) and the maxilliped with only seven armature elements (Figure 17). It differs from $M$. pilbaricus sp. nov. also by the habitus shape from dorsal view (Figures 1 and 3), seminal receptacle (Figures 4 and 30 ), caudal rami shape (Figures 9 and 35) and the fifth leg (Figures 21 and 38). Metacyclops kimberleyi has enormous maxillae (Figure 8), which extend far away from the body, although there is nothing unusual in the morphology of these conservative appendages other than their size. This may be one of the preadaptations for a predatory way of life, which may be further supported by its robust habitus and large body (for a subterranean species) and also by the morphology of the maxilliped, which is equipped with fewer but much stronger setae and looks like a more powerful grasping organ than in other members of the "trispinosus"-group. Metacyclops pilbaricus can be distinguished from each member of the group by a number of characters, but the only clear autapomorphy of this species is its unusual body shape (Figure 3), which is more harpacticoid-like (without very obvious distinction between prosome and urosome). It should be also noted here that both $M$. kimberleyt and $M$. pilbaricus have a very smooth surface of all somites and appendages (Figures 46, 48 and 50), while $M$. laurentisae and $M$. pilanus have numerous cuticular pits (Figures 46, 49, 51 and 53). The situation of this character is not known in $M$. arnandi. Although there is little doubt that the five
Australian representatives of the "trispinosus"group share a common ancestor, the phylogenetic position of this group within the genus Metacyclops, as well as the position of the other two Australian Metacyclops, is currently unclear. These questions are not always easy to answer even in groups where we have a full set of morphological, physiological, behavioral, ecological and molecular characters, so they would need to wait until at least a proper morphological revision of the genus Metacyclops can be presented.

As the genus Metacyclops in Australia already has seven valid species, a key to aid in their identification is presented below as well as a map of their distributions (Figure 45).

\section{Key to the Australian Metacyclops species}

1. Swimming legs with second exopodal segment

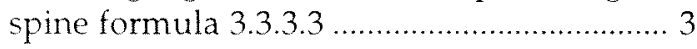

Spine formula different ................................... 2

2. Spine formula 3.4 .4 .3

M. superincidentis Karanovic, 2004

Spine formula 3.4 .4 .2

M. mortoni Pesce et al., 1996

3. Exopod of antenna present; second endopodal segment with 9 setae ......................................4

Exopod of antenna absent; second endopodal segment with 6 setae ... 6

4. Caudal rami not more than 4 times as long as wide.

Caudal rami about 7 times as long as wide ..... M. arnaudi (Sars, 1908)

5. Dorsal seta on caudal ramus shorter than outermost apical one

M. laurentiisae Karanovic, 2004

Dorsal seta longer than outermost apical one.. M. pilanus Karanovic, 2004

6. Dorsal seta on caudal ramus about as long as ramus. M. pilbaricus sp. nov

Dorsal seta more than twice as long as ramus. M. kimberleyi sp. nov.

\section{ACKNOWLEDGEMENTS}

This study was financially supported by the Department of Conservation and Land Management (Pilbara Region Biological Survey 2002-2007) and by the Argyle Diamond Mine. The material was kindly provided by Dr William F. Humphreys (WA Museum). Thanks are extended to the Western Australian Museum for kindly granting me the status of research associate. I am also grateful to Dr Mark S. Harvey (WA Museum) for his valuable comments on an early draft of this paper. 


\section{REFERENCES}

Bayly, I. A. E. (1964). Chemical and biological studies on some acidic lakes of east Australian sandy coastal lowlands. Australian Journal of Marine and Freshwater Research 15: 56-72.

Bayly, I. A. E. and Williams, W. D. (1964). Chemical and biological observations on some volcanic lakes in the south-east of South Australia. Australian Journal of Marine and Freshwater Research 15: 123-132.

Bayly, I. A. E. and Williams, W. D. (1966a). Chemical and biological studies on some saline lakes of south-east Australia. Australian Journal of Marine and Freshwater Research 17: 177-228.

Bayly, I. A. E. and Williams, W. D. (1966b). Further chemical observations on some volcanic lakes in the south-east of South Australia. Australian Journal of Marine and Freshwater Research 17: 229-237.

Danielopol, D. L., Baltanás, A. and Humphreys, W. F. (2000). Danielopolina kornickeri sp. n. (Ostracoda: Thaumatocypridoidea) from a western Australian anchialine cave - morphology and evolution. Zoologica Scripta 29: 1-16.

De Laurentiis, P., Pesce, G. L. and Humphreys, W. F. (1999). Copepods from ground waters of Western Australia, IV. Cyclopids from basin and craton aquifers (Crustacea: Copepoda: Cyclopoida). Records of the Western Australian Museum 19: 243-257.

De Laurentiis, P., Pesce, G. L. and Humphreys, W. F. (2001). Copepods from ground waters of Western Australia, VI. Cyclopidae (Crustacea: Copepoda) from the Yilgarn Region and the Swan Coastal Plain. Records of the Western Australian Museum, supplement 64: 115-131.

Dumont, H. J. (1981). Cladocera and free-living Copepoda from Fouta Djalon and adjecent mountain areas in West Africa. Hydrobiologia 85: 97-116.

Dussart, B and Defaye, D. (1985). Répertoire Mondial des Copepodes Cyclopoides. Editions du Centre National de la Recherche Scientifique, Centre Régional de Publications de Bordeaux.

Fiers, F. (2001). Meridiecyclops, gen. nov., a new cyclopoid genus (Crustacea: Copepoda: Cyclopidae) from southern Australia. Invertebrate Taxonomy 15: 893-908.

Hamond, R. (1987). Non-marine harpacticoid copepods from Australia, I. Canthocamptidae of the genus Canthocamptus Westwood s. lat., and Fibulocamptus gen. nov., and including the description of a related species of Canthocamptus from New Caledonia. Invertebrate Taxonomy 1: 1023-1247.

Humphreys, W. F. (1993). Stygofauna in semi-arid tropical Western Australia: a Tethyan connection? Mémoires de Biospéologie 20: 111-116.

Humphreys, W. F. (2001). Groundwater calcrete aquifers in the Australian arid zone: the context to an unfolding plethora of stygal biodiversity. Records of the Western Australian Museum, supplement 64: 63-83.

Huys, R. and Boxshall, G. A. (1991). Copepod evolution. The Ray Society, London.

Jaume, D., Boxshall, G. A. and Humphreys, W. F. (2001). New stygobiont copepods (Calanoida; Misophrioida) from Bundera sinkhole, and anchialine cenote on north-western Australia. Zoological Journal of the Limnean Society 133: 1-24.

Jaume, D. and Humphreys, W. F. (2001). A new genus of epacteriscid calanoid copepod from an anchialine sinkhole in northwestern Australia. Journal of Crustacean Biology 21: 157-169.

Karanovic, T. (1999). First record of Metacyclops stammeri Kiefer, 1938 from Balkan Peninsula (Crustacea, Copepoda). Spixiana 22: 193-198.

Karanovic, T. (2004). Subterranean copepods (Crustacea: Copepoda) from arid Western Australia. Crustaceana Monographs 3: 1-366.

Kiefer, F. (1927). Versuch eines Systems der Cyclopiden. Zoologischer Anzeiger 73: 302-308.

Kiefer, F. (1928). Beiträge zur Copepodenkunde (VIII). Zoologischer Anzeiger 76: 5-18.

Kiefer, F. (1967). Cyclopiden aus Salzhaltigen Binnengewässern Australiens (Copepoda). Crustaceana 12: 292-302.

Lindberg, K. (1938). Cyclopides (Crustaces Copepodes) nouveaux de l'Inde. Bulletin de la Sociéte Zoologique de France 63: 288-302.

Pesce, G.L., De Laurentiis, P. and Humphreys, W. F. (1996). Copepods from ground waters of Western Australia, I. The genera Metacyclops, Mesocyclops, Microcyclops and Apocyclops (Crustacea: Copepoda: Cyclopoida). Records of the Western Australian Museum 18: $67-76$.

Plesa, C. (1981). Cyclopides (Crustacea, Copepoda) de Cuba. Résultats des expeditions biospéologiques cubanoroumaines à Cuba 3: 17-34.

Poore, G. C. B. and Humphreys, W. F. (1992). First record of Thermosbaenacea (Crustacea) from the Southern Hemisphere: a new species from a cave in tropical Western Australia. Invertebrate Taxonomy 6: 719-725.

Poore, G. C. B. and Humphreys, W. F. (1998). First record of Spelaeogriphacea from Australasia: a new genus and species from a aquifer in the arid Pilbara of Western Australia. Crustaceana 71: 721-742.

Reid, J. W. (1987). The cyclopoid copepods of a wet campo marsh in central Brazil. Hydrobiologia 153: 121138.

Sars, G. O. (1908). Fresh-water Copepoda from Victoria, Southern Australia. Archiv for Mathematik og Naturvidenskab 27: 3-24.

Stock, J. H. and von Vaupel Klein, J. C. (1996). Mounting media revisited: the suitability of Reyne's fluid for small crustaceans. Crustaceana 69: 749-798.

Timms, B. V. and Morton, D. W. (1988). Crustacean zooplankton assemblages in fresh waters of tropical Australia. Hydrobiologia 164: 161-169.

Wilson, G. D. F. and Ponder, W. F. (1992). Extraordinary new subterranean isopods (Peracarida: Crustacea) from the Kimberley Region, Western Australia. Records of the Australian Museum 44: 279-298.

Yager, J. and Humphreys, W. F. (1996). Lesionectes exleyi, sp. nov, the first remipede crustacean recorded from Australia and the Indian Ocean, with a key to the world species. Invertebrate Taxonomy 10: 171-187.

Manuscript received 25 July 2003; accepted 2 March 2004 